\title{
Diversity of the definition of stable vital sign in trauma patients: results of a nationwide survey
}

\author{
Seongpyo Mun, M.D.
}

Department of Surgery, Chosun University, Gwangju, South Korea

\begin{abstract}
BACKGROUND: Hemodynamic stability (HS) based on vital sign (VS) is thought to be the most useful criteria for successful nonoperative management (NOM) of blunt spleen injury (BSI). However, a consistent definition of HS has not been established. We wanted to evaluate the definition of HS through conducting a nationwide survey and find the factors affectting diversity.

METHODS: The questionnaire regarding the definition of HS was sent to the department of trauma surgery and emergency medicine of level I trauma center between October 2012 and November 2012. Data was compared using analysis of variance, t-test, $\chi^{2}$ test and logistic regression.

RESULTS: Among five hundred and sixty-three doctors, 507 responded (90\%). Forty-eight responses were incomplete, and hence, 459 (8I.5\%) responses were analyzed. There was a significant diversity in the definition of HS on the subject of type of blood pressure (BP), cut off value of hypotension, measuring technique of $\mathrm{BP}$, duration of hypotension, whether or not using heart rate (HR) as a determinant of $\mathrm{HS}$, cut off value of hypotension when the patient has comorbidity or when the patient is a pediatric patient. $91.5 \%$ replied that they were confused defining HS and felt the need to have more objective determinants. Nevertheless, $90 \%$ of the responders were not using laboratory test to define HS.
\end{abstract}

CONCLUSION: Many trauma doctors are using only VS to define HS. This is why there is a confusion regarding how to define which patient is hemodynamically stable. More objective determinants such as base deficit or lactate can be useful adjuncts.

Key words: Blunt spleen injury; definition; diversity; hemodynamic instability; survey.

\section{INTRODUCTION}

Trauma is still a major cause of death in young people under the age of 50. Blunt abdominal injury is common in trauma patients. Spleen is the most frequently injured organ in blunt abdominal trauma and hemorrhagic shock is the main cause of death. When hemoperitoneum caused by spleen injury is detected, exploratory laparotomy is usually performed. ${ }^{[1]}$ However, with the increased use of computerized tomography (CT) scanning and focused assessment with sonography for trauma (FAST), nonoperative management (NOM) of blunt spleen injury (BSI) has been introduced, and is being actively used in many countries. ${ }^{[2-4]}$ Most trauma doctors agree

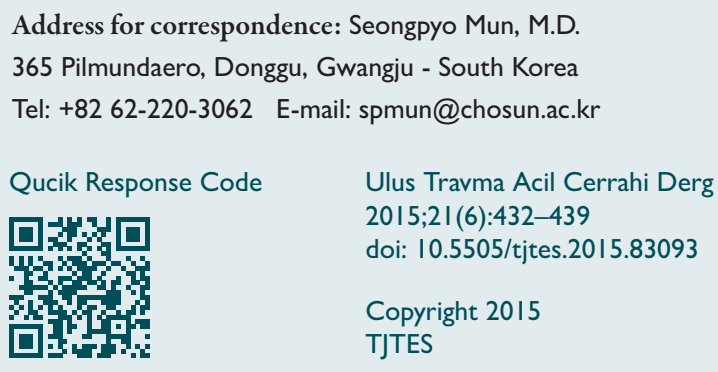

that cautious selection of the patient is fundamental for the success of NOM in BSI. Many selection criteria have been suggested and evaluated for this purpose and examples are vital sign, FAST, CT scan, injury scale or laboratory tests. ${ }^{[5-7]}$

Hemodynamic stability (HS) based on vital sign is being used most frequently. However, a consistent definition of "hemodynamic stability" is lacking. There is a possibility that trauma doctors are using a different definition, numerical value, and an obtaining method to define HS. We wanted to evaluate the diversity of the definition of HS through conducting a nationwide survey and provide the suggestion to unify the diversity of the definition of HS.

\section{MATERIALS AND METHODS}

\section{Questionnaire and Survey}

A nationwide survey was performed between October 2012 and November 2012. The questionnaire was composed of 3 sections; 6 questions about biography, career, and circumstances of working environment, II questions about the definition of HS based on the simulated trauma case, and 7 questions about personal opinions regarding the definition of HS (Table I). The questionnaire was sent to the attending 
Table I. Details of the questionnaires

\section{Section I. Biography, career and circumstances of working} environment

I. How OLD are you?

2. What is your SEX?

(1) Male (2) Female

3. How LONG have you been working for the management of trauma patients?

4. How many DAYS are you on duty for trauma patient in a MONTH?

\section{How do you DEFINE yourself?}

(1) attending, general surgery (2) attending, emergency medicine

(3) fellow, general surgery $\quad$ (4) fellow, emergency medicine

(5) resident, general surgery (6) resident, emergency medicine

6. On average, how many TRAUMA PATIENTS do you treat a month?

Section 2. Definition of HS based on the simulated trauma case 50 -year-old male patient $(170 \mathrm{~cm} / 70 \mathrm{~kg})$ fell down from 2 meter high ladder on his left frank area. VSs at ED admission were BP 90/60 mmHg, HR 120/minute, RR 20/minute, BT 37.5 oC. GCS was 15 and the mental status was drowsy. There was no specific abnormality. $2 \mathrm{~L}$ of normal saline was infused rapidly while FAST revealed isolated spleen laceration and large amount of fluid around perirenal and perisplenic area. Secondary VS is being checked.

I. Which parameter(s) of VS(s) do you use as a determinant of your definition of hemodynamic instability? (BP: blood pressure, HR: heart rate, RR: respiration rate, BT: body temperature; check all that apply)
(1) BP
(2) $\mathrm{HR}$
(3) RR
(4) $\mathrm{BT}$

2. What KINDS of blood pressure do you use to determine the HS?
(1) SBS
(2) DBP
(3) MAP
(4) pulse pressure
(5) others

3. What is your highest cut off value of HYPOTENSION to make you carry out emergent exploratory laparotomy? (Systolic BP, $\mathrm{mmHg}$ )

4. What kind of measuring TECHNIQUE do you use to decide if the patient is hypotensive?
(1) manual
(2) automated cuff
(3) arterial line

(4) at least two of them (5) all three of them (6) does not matter

5. How LONG do you feel the patient should be hypotensive before you to decide to carry out emergent exploratory laparotomy? (Minutes)

6. Do you use HEART RATE as an independent determinant of exploratory laparotomy regardless of hypotension?

(1) Yes (2) No

7. What is your cut off value of TACHYCARDIA to make you carry out emergent exploratory laparotomy regardless of hypotension? (/minute)

8. Do you have a different cut-off value of hypotension in case the patient has been taking medication which affects vascular system such as antihypertensives or anticoagulation?

(1) Yes (2) No

9. Do you have different cut-off value of hypotension in case the patient has medical condition such as hypertension, diabetes, asthma etc? (1) Yes (2) No

10. If the patient is 5 to 15 year old children, do you feel like to use the different cut off value contrary to the adult's for the emergent $z$ ? (1) Yes (2) No

II. If the patient is a 5 to 15 year old child, what is your cut off value of blood pressure that makes you carry out emergent laparotomy? $(\mathrm{mmHg})$

\section{Section 3. Personal opinions about the definition of HS}

I. Do you use BASE DEFICIT as an independent determinant to carry out emergent exploratory laparotomy regardless of hemodynamic instability?

(1) Yes (2) No

2. Do you use serum lactate level as an independent determinant to carry out emergent exploratory laparotomy regardless of hemodynamic instability?

(1) Yes (2) No

3. Do you feel like carrying out emergent laparotomy when the patient has high grade spleen injury (grade IV or V) although the patient is hemodynamically stable?

(1) Yes (2) No

4. Do you agree using classic concept of hemodynamic instability (BP $\leq 90 \mathrm{mmHg}$ AND HR $\geq 100 / \mathrm{min}$ ) in order to decide the necessity of exploratory laparotomy
(1) strongly agree
(2) mildly agree
(3) neutral
(4) mildly disagree (5) strongly disagree

5. What is the reason for you to agree using the classic definition of hemodynamic instability? Because,

(1) I believe it is evidence based medicine

(2) I have learned like that from my senior, medical conference, textbook etc

(3) the range seems to be optimal
(4) Others (
)
(5) do not agree

6. Do you feel the need to have a more clear and objective parameter in determining to carry out exploratory laparotomy in spleen injury? (1) strongly agree (2) mildly agree (3) neutral (4) mildly disagree (5) strongly disagree

7. Do you have any comments? ( 
doctors, fellows and residents of the department of trauma surgery and emergency medicine of the level I trauma center. The survey was performed through email and an online survey program. It was analyzed under complete confidentiality. This study was approved by Chosun University Hospital IRB.

\section{Statistical Analysis}

Data were compared using analysis of variance (ANOVA) or t-test for continuous variables and $\chi^{2}$ test for categorical variables. Logistic regression was carried out to evaluate the variables which influence trauma doctors to make a diversity of $\mathrm{HS}$.

\section{RESULTS}

\section{Section 1 of the Questionnaire}

Among five hundred and sixty-three doctors, 507 responded (90\%). Forty eight responses were incomplete, and hence, 459 responses were analyzed (8I.5\%). The average age of the respondents was 46 . Of the respondents, four hundred and fourteen (90.2\%) were male. They had been working for eighteen years on average. They were on duty for four days and treated three trauma patients per month. Seventy one (15.5\%) were attending doctors of TS and eighty three (18.1\%) were attending doctors of ED. Forty three $(9.4 \%)$ were the fellows of TS and forty eight (10.5\%) were the fellows of ED. One hundred and six (23.I) were the residents of TS and I08 (23.5) were the residents of ED (Table 2).

\section{Section 2 of the Questionnaire}

When defining HS, one hundred and ninety-eight (43.1\%) used only blood pressure (BP), I 86 (40.5\%) used both BP and heart rate (HR), and 54 (II.8\%) used only HR. Eighteen of them used respiratory rate or body temperature as an adjunct of determinant. Two hundred and eighty-five (62.1\%) considered systolic blood pressure (SBS) to define HS, I 35 (29.4\%) considered mean arterial pressure (MAP) and 39 (8.5\%) considered diastolic blood pressure (DBP). One hundred and eighty-nine (4I.2\%) used manual technique to check BP, I I I (24.2\%) preferred automated cuff, I50 (32.7\%) had no preference. Two hundred and eighty-five respondents who took account of SBP thought emergent laparotomy should be carried out when SBP was $\leq 94 \mathrm{mmHg}$ on average. $73 \%$ of the respondents located between 80 to $99 \mathrm{mmHg}$ and the cut off value of hypotension ranged widely from 59 and $104 \mathrm{mmHg}$ (Table 3). The duration of hypotension to make them carry out EL was 1.5 minutes (0-30 minutes). One hundred and eleven respondents (24.2\%) used HR as an independent determinant of hemodynamic stability. On average, they thought EL should be carried out when HR was $\geq 109 / \mathrm{min}$. One hundred and ninety-eight (43.1\%) used a different cut off value of BP when the patient was on vasoactive medicine. Two hundred and thirty-one (50.3\%) of the respondents used a different value of BP when the patients had medical comorbidity. Three hundred and seventy-eight ${ }^{[8]}(82 \%)$ used a lower cut-off value
Table 2. The results of Section I questionnaire $(\mathrm{No}=459)$

\begin{tabular}{lc}
\hline Characteristics & No (range or \%) \\
\hline $\begin{array}{l}\text { Age (year) } \\
\text { Sex }\end{array}$ & $46.7(28-62)$ \\
$\quad$ Male & $414(90.2)$ \\
$\quad$ Female & $45(9.8)$ \\
Career (year) & $18(3-31)$ \\
NO of New trauma patients per week & $3.1(0-15)$ \\
Definition of self & \\
$\quad$ Attending & $71(15.5)$ \\
$\quad$ Trauma surgery & $83(18.1)$ \\
$\quad$ Emergency medicine & \\
Fellow & $43(9.4)$ \\
$\quad$ Trauma surgery & $48(10.5)$ \\
$\quad$ Emergency medicine & $106(23.1)$ \\
Resident & $108(23.5)$ \\
Trauma surgery &
\end{tabular}

No: Numbers.

of hypotension to define HS in pediatric patients and the value of BP was distributed from 60 to $99 \mathrm{mmHg}$. On average, they thought EL should be carried out when BP was equal or below $85 \mathrm{mmHg}$ or HR was equal or above II9/minute (Table 3).

\section{Section 3 of the Questionnaire}

Four hundred and seventeen respondents (90.8\%) did not use base deficit as determinants of HS. Four hundred and twentythree of them (92.2\%) did not use lactic acid as a determinant of HS. Two hundred and ninety-one respondents (63.4\%) replied that they would not perform emergency laparotomy even when the injury grade was high as long as the patient was hemodynamically stable. One hundred and eighty-three (39.9\%) agreed to use the classic definition of hypotension; $\mathrm{BP}<90 \mathrm{mmHg}$ and $\mathrm{HR} \geq 120 /$ minute. One hundred and seventeen respondents $(25.5 \%)$ agreed to use the classic definition because they thought it was evidence based medicine. One hundred and twenty-three agreed because they believed they were supposed to follow classic definition. Seventytwo respondents replied that the range of classic definition seemed to be optimal. Four hundred and twenty respondents (91.5\%) replied that they were confused defining HS and felt the need for more objective determinants (Table 4).

\section{Univariate and Multivariate Analysis}

In univariate analysis, factors that were significantly associated with the respondents defining HS differently with the classic definition were younger $(<40)$, female trauma doctors with a short career ( $<5$ years). The diversity of HS seems to be 
Table 3. The results of Section 2 questionnaire

\section{Characteristics}

Determinants to define heart rate

$\begin{array}{lc}\text { Blood pressure } & 198(43.1) \\ \text { Heart rate } & 54(11.8) \\ \text { Respiratory rate } & 0(0) \\ \text { Body temperature } & 0(0) \\ \text { Blood pressure and heart rate } & 186(40.5) \\ \text { Blood pressure and respiratory rate } & 6(1.3) \\ \text { Blood pressure and body temperature } & 12(2.6) \\ \text { Others } & 3(0.7)\end{array}$

Favorite blood pressure to define hemodynamic stability

Systolic blood pressure

Diastolic blood pressure

Mean arterial pressure

Pulse pressure

Others

Cut off value of blood pressure to carry out emergent laparotomy

Technique to check blood pressure to define hemodynamic stability

Manual

Automated cuff

Arterial line

Do not care

Duration of hypotension (minutes) to define as hemodynamic instability

Using heart rate as independent determinants

Yes

No

Cut off value of heart rate to carry out emergent laparotomy

Using different value in case taking vasoactive agents

Yes

No

Using different value in case having medical comorbidity

Yes

No

Using different value to define HS in pediatrics

Yes

$378(82.4)$

No

81 (17.6)

Cut off value of blood pressure to carry out emergent laparotomy in pediatrics

85 (60-99)

more prevalent among young doctors. Not agreeing to use the classic definition of HS was only significant in multivariate analysis (Table 5).

\section{DISCUSSION}

When there is intraperitoneal hemorrhage due to BSI, trauma doctors have to decide whether the patient needs emergent operation or not. Before the 1980s, operative treatment was prevalent regardless of the severity of the spleen injury. However, some doctors observed that patients could be cured by NOM and tried to find the criteria for successful outcomes. $[1,8,9]$ The first suggested determinant was radiologic findings. 
Table 4. Results of Section 3 questionnaire

\begin{tabular}{|c|c|c|c|}
\hline Categories & Number & $\%$ & $\mathbf{p}$ \\
\hline \multicolumn{4}{|l|}{ Using base deficit } \\
\hline Yes & 42 & 9.2 & \\
\hline No & 417 & 90.8 & $<0.01$ \\
\hline \multicolumn{4}{|l|}{ Using lactic acid } \\
\hline Yes & 36 & 7.8 & \\
\hline No & 423 & 92.2 & $<0.01$ \\
\hline \multicolumn{4}{|l|}{ Carrying out emergent laparotomy based on radiologic finding } \\
\hline Yes & 168 & 36.6 & \\
\hline No & 291 & 63.4 & $<0.05$ \\
\hline \multicolumn{4}{|l|}{ Agreeing to the classic definition* of hemodynamic stability } \\
\hline Strongly agree & 84 & 18.3 & \\
\hline Mildly agree & 99 & 21.6 & \\
\hline Neutral & $|4|$ & 30.7 & \\
\hline Mildly disagree & 81 & 17.6 & \\
\hline Strongly disagree & 54 & 11.8 & \\
\hline \multicolumn{4}{|l|}{ Reason to agree to classic definition of hemodynamic stability } \\
\hline I believe it is evidence based medicine & 117 & 25.5 & \\
\hline I have learned like that from my senior, medical conference, textbook etc & 123 & 26.8 & \\
\hline The range seems to be optimal & 72 & 15.7 & \\
\hline Others & 12 & 2.6 & \\
\hline Do not agree & 135 & 29.4 & \\
\hline \multicolumn{4}{|l|}{ Feeling the necessity to use other objective parameters } \\
\hline strongly agree & 225 & 49.0 & $<0.01^{* *}$ \\
\hline Mildly agree & 195 & 42.5 & \\
\hline Neutral & 24 & 5.2 & \\
\hline Mildly disagree & 15 & 3.3 & \\
\hline Strongly disagree & 0 & 0 & \\
\hline
\end{tabular}

*: $\mathrm{SBP}<90 \mathrm{mmHg}$ and $\mathrm{HR} \geq 120 /$ minute; **: Comparison between agreeing group and disagreeing group.

McKenney et al. suggested a unique hemoperitoneum score system calculated by FAST. They calculated the depth in centimeters of the largest collection from the abdominal wall plus the total additional areas positive for fluid. Forty of 46 patients $(87 \%)$ with a score $\geq 3$ required therapeutic laparotomy. Forty-six of 54 patients (85\%) with a score $<3$ did not need operative intervention. The sensitivity of the score in determining the need for therapeutic operation was higher than systolic blood pressure (83\% vs $28 \%) .{ }^{[10]}$ Starnes et al. reviewed the role of computed tomography (CT) grade in NOM of BSI. The only significant difference between the success and failure of NOM was CT grade (I.47 vs 3.5; $\mathrm{p}=0.000 \mathrm{I}$ ). Although the amount of hemoperitoneum and the grade of injury are useful to evaluate the severity of the patients, NOM is regarded reasonable as long as the patient is hemodynamically stable. Radiologic findings cannot be an absolute contraindication for NOM nowadays. In our survey, $63.4 \%$ did not consider the amount of hemoperitoneum as a determinant of NOM. It is a well accepted concept for the trauma doctor to perform NOM regardless of radiologic findings.

Hemodynamic stability (HS) has been suggested and evaluated vigorously in many studies attempting to find the selection criteria for NOM. Longo et al. have reviewed sixty patients managed successfully with NOM. They have concluded that hemodynamic stability after initial fluid challenge is a useful predicting factor. Despite prioritizing HS in initial decisionmaking, they have not made a description of the definition of HS. ${ }^{\left[{ }^{\prime I}\right]}$ Lynch, Wasvary and Siplovich also have not described the definition of HS. ${ }^{[12,13]}$ Some studies have described the definition of HS using only VS. However, the numeric value and the determinants are frequently different. They have defined $\mathrm{HS}$ as $\mathrm{BP} \geq 90 \mathrm{mmHg},{ }^{[14-18]} \geq 100 \mathrm{mmHg},{ }^{[19,20]}$ and $\geq 110$ $\mathrm{mmHg}$ (Table 6). ${ }^{[21]}$ Besides the numeric value, the type of BP 
Table 5. Variables associated with the respondent who has cut off value different from classic definition of hemodynamic stability

\begin{tabular}{lcc}
\hline Variable & \multicolumn{2}{c}{ Odds Ratio (95\% Cl) } \\
\cline { 2 - 3 } & Univariate analysis & Multivariate analysis \\
\hline Age $<40$ & $1.23(1.03-2.14)$ & $0.48(0.14-1.76)$ \\
Female Sex & $1.12(1.02-1.98)$ & $0.13(0.12-1.75)$ \\
Short career less than 5 year & $1.54(1.17-2.56)$ & $0.33(0.14-1.36)$ \\
Do not agree to classic definition & $8.65(5.67-9.45)$ & $4.67(3.17-6.38)$ \\
\hline
\end{tabular}

Only variables that were significant in the univariate analysis are listed. $\mathrm{Cl}$ : Confidence interval.

and the measuring technique of BP are amongother diversities. There are basically three methods of measuring blood pressure; manual auscultatory method, automated cuff and arterial line. It is well known that there is a discrepancy between these methods. ${ }^{[22-24]}$ In spite of the variability of the method of obtaining BP, most studies do not elucidate the method they use to determine HS. In our study, 62.1\% used SBP to define HS. However, the others used MAP and DBP. There is no study evaluating the sensitivity of the type of BP to define HS. Therefore, it is hard to determine which type of BP should be used. Another well-known determinant of $H S$ is heart rate $(H R)$. Some authors have included $H R$ as a determinant while others have not. Tachycardia appears earlier than hypotension in hypovolemic status. When a patient losesbetween 750 to $1500 \mathrm{ml}$ of blood, BP is normal but HR increases to 100-120/min. Physiologically, HR is more sensitive. However, tachycardia can result from pain, emotional status or heart problem regardless of volume status. It makes us hesitate to use HR as an independent determinant of HS. Only $24.2 \%$ used HR as an independent determinant of HS in our study, meaning thatHR is regarded as an unreasonable determinant of HS for the trauma doctor. Considering the duration of hypotension or tachycardia, the problem of diversity gets more complicated. Some responders decided to

Table 6. Studies that insist the usefulness of HS for successful NOM in BSI

\begin{tabular}{|c|c|c|c|c|c|}
\hline Author & Year & Study type & $\begin{array}{c}\text { No of patients/ } \\
\text { Age (year) }\end{array}$ & Criteria for NOM & Definition of \\
\hline Longo & 1989 & Retrospective & $60 / \geq 16$ & $\mathrm{HS}$, transfusion $<4 \mathrm{U}$ age $<50$ & None \\
\hline William & 1990 & Retrospective & I6/all age & Hemodynamic stability & $\mathrm{SBP} \geq 90 \mathrm{mmHg}$ \\
\hline Lynch & 1993 & Retrospective & 48/unknown & Hemodynamic stability, Class I, II and III & None \\
\hline Archer & 1996 & Retrospective & $87 / \geq 16$ & Hemodynamic stability & $\mathrm{SBP} \geq 90 \mathrm{mmHg}$ \\
\hline Clancy & 1996 & Retrospective & $31 /$ all age & HS, low injury severity score, CT scan & $\mathrm{SBP} \geq 90 \mathrm{mmHg}$ \\
\hline Wasvary & 1997 & Retrospective & 40/all age & HS, no evidence of decreased sensorium & None \\
\hline Siplovich & 1997 & Retrospective & $55 / \leq 14$ & clinical response to injury $C T$ grade & None \\
\hline Cathey & 1998 & Retrospective & 38/all age & $\begin{array}{l}\text { Hemodynamic stability, } \\
\text { no multiple injuries, } \\
\text { normal laboratory finding } \\
\text { no transfusion }\end{array}$ & $\begin{array}{l}\mathrm{SBP} \geq 100 \mathrm{mmHg} \\
\text { and } \mathrm{HR} \leq 100 / \mathrm{min}\end{array}$ \\
\hline Konstantakos & 1999 & Retrospective & I47/all age & Hemodynamic stability & $\begin{array}{l}\mathrm{SBP} \geq \mathrm{I} 20 \mathrm{mmHg} \\
\text { and } \mathrm{HR} \leq 95 / \mathrm{min}\end{array}$ \\
\hline Krause & 2000 & Retrospective & $\mid 8 / \geq 55$ & $\begin{array}{l}\text { HS, Transfusion }<2 \text { Unit } \\
\text { No associated abdominal } \\
\text { injury }\end{array}$ & $\mathrm{SBP} \geq 100 \mathrm{mmHg}$ \\
\hline Brasel & 2003 & Retrospective & 20/all age & Hemodynamic stability & $\begin{array}{l}\mathrm{SBP} \geq 90 \mathrm{mmHg} \\
\text { and } \mathrm{HR} \leq 100 / \mathrm{min}\end{array}$ \\
\hline Watson & 2006 & Retrospective & |392/all age & Hemodynamic stability, Low grade & $\mathrm{SBP} \geq 90 \mathrm{mmHg}$ \\
\hline
\end{tabular}

BSI: Blunt spleen injury; HS: Hemodynamic stability; NOM: Nonoperative management; SBP: Systolic blood pressure; HR: Heart rate. 
carry out EL as long as the patient was hypotensive at least once. Some observed for 30 minutes (Table 3). However, there is no constant definition of the duration of hypotension or tachycardia to define HS. When the patient has medical problems, defining HS is harder. ${ }^{[25]}$ Confusion in defining HS also happens when the patient has spinal cord injury or when the patient was previosly on vasoactive medication. ${ }^{[26]}$ Most trauma doctors agree to use lower cut off value of hypotension to define HS for pediatric patients, but there is no study defining the numeric value of VS of HS according to the age of the patients. Many retrospective studies, concluding that NOM in BSI of pediatric patients is more reasonable than that of the adults, have actually failed to explain the clear definition of HS. ${ }^{[27,28]}$ Much of the confusion and variability of the definition of HS is caused by using VS to define HS. Contrary to laboratory test or radiologic findings, VS is too diverse in terms of obtaining method, normal physiologic value, type, and duration. The only way to unify the diversity is a randomized prospective study. Unfortunately, prospective studies to define HS are unlikely to be performed due to concerns over patient's safety. We tried to find out the factors influencing the responders to make the diversity of HS. Although young age, female sex and short career seemed to be significant in the univariate analysis, there was no significant factor in the multivariate analysis, meaning thatthe problem of the diverse definition of HS is universal (Table 5).

Contrary to VS, laboratory test of anaerobic metabolism like arterial base deficit or venous lactate are more objective and can be used in conjunction with VS to define HS. Bannon et al. have evaluated the efficacy of arterial base deficit and lactate concentration in trauma patients. They prospectively studied forty patients with truncal injuries to examine the usefulness of central venous oxygen saturation ( $\mathrm{ScvO} 2)$, arterial lactate concentration, and arterial base deficit. Both base deficit and lactate concentration correlated with transfusion requirements; in addition, base deficit (BD) correlated with trauma score, and lactate correlated with the amount of hemoperitoneum. ${ }^{[29]}$ Rixen et al. have also performed a prospective, multi-center, observational study of 2,069 multiple trauma patients to evaluate the significance of BD. BD was associated with a significant decrease in systolic blood pressure, prothrombin time, amount of transfusion, and mortality. Their data showed that BD was an early available important indicator of hemodynamic instability in trauma patients and predicted higher probability of death. ${ }^{[30-32]} \mathrm{BD}$ and lactate are laboratory tests that can be available in the emergency room. There is only one method to get the results, that is, blood sampling regardless of sampling site. The results are revealed by numeric value. Normal physiologic range is not diverse at all. Thus, they can be useful adjuncts in assessing HS in trauma patients. Based on these studies, some authors insist to use lactic acid and BD as a determinant of HS. Some national guidelines suggest using BD or lactate. One of them is as following; regardless of causes, the patient is defined hemodynamically unstable if four of the following cri- teria meet. ${ }^{[33]}$ (I) acutely ill-looked appearance or deterioration of mental status; (2) $H R \geq 100 /$ minute; (3) $R R \geq 22 /$ min or $\mathrm{PaCO}_{2} \leq 2 \mathrm{lmmg}$; (4) arterial $\mathrm{BD} \leq-5 \mathrm{mEq} / \mathrm{L}$ or lactic acid $\geq 4 \mathrm{mM} / \mathrm{L}$; (5) urine out $<0.5 \mathrm{ml} / \mathrm{kg} /$ hour; (6) hypotension (systolic blood pressure $<90 \mathrm{mmHg}$ ) lasts longer than 20 minutes. Most trauma doctors agree that HS should be defined systematically using patient's symptoms and signs, VS, laboratory test. It is quite surprising that many trauma doctors are still using only VS to define HS even though there are several studies suggesting objective determinants. In order to standardize NOM for trauma patients, the diversity of the definition of HS should be unified and a more objective determinant should be used.

\section{Conclusion}

Trauma doctors are using VS as major determinants to define $\mathrm{HS}$, resulting indiverse definitions of HS for patients with BSI. There is confusion regarding how to define which patient is HS. Most surveyed respondents felt the need for the clarification of HS and how it should be used to determine NOM versus operation. Using patients' symptoms and signs, base deficit and lactic acid can minimize diversity and aid in the decision making process.

\section{Acknowledgement}

The present study was supported by grants from Chosun University 2015.

Conflict of interest: None declared.

\section{REFERENCES}

1. Hebeler RF, Ward RE, Miller PW, Ben-Menachem Y. The management of splenic injury. J Trauma 1982;22:492-5. CrossRef

2. Cooney DR, Michalak WA, Michalak DM, Fisher JE. Comparative methods of splenic preservation. J Pediatr Surg 1981;16:327-38. CrossRef

3. Popovsky J, Wiener SN, Felder PA, Biramje A, Reydman M. Liver trauma: conservative management and the liver scan. Arch Surg 1974;108:184-6.

4. Yoo SY, Lim KS, Kang SJ, Kim CS. Pitfalls of nonoperative management of blunt abdominal trauma in children in Korea. J Pediatr Surg 1996;31:263-6. CrossRef

5. Fifer T, Obeid FN, Sorensen VJ, Horst HM, Bivins BA. Comparative accuracy of diagnostic peritoneal lavage, liver-spleen scintigraphy, and visceral angiography in blunt abdominal trauma. Am Surg 1989;55:612-5.

6. Starnes S, Klein P, Magagna L, Pomerantz R. Computed tomographic grading is useful in the selection of patients for nonoperative management of blunt injury to the spleen. Am Surg 1998;64:743-9.

7. Köksal N, Uzun MA, Müftüoğlu T. Hemodynamic stability is the most important factor in nonoperative management of blunt splenic trauma. Ulus Travma Derg 2000;6:275-80.

8. Morgenstern L, Uyeda RY. Nonoperative management of injuries of the spleen in adults. Surg Gynecol Obstet 1983;157:513-8.

9. Zucker K, Browns K, Rossman D, Hemingway D, Saik R. Nonoperative management of splenic trauma. Conservative or radical treatment? Arch Surg 1984;119:400-4. CrossRef

10. McKenney KL, McKenney MG, Cohn SM, Compton R, Nunez DB, 
Dolich M, et al. Hemoperitoneum score helps determine need for therapeutic laparotomy. J Trauma 2001;50:650-6. CrossRef

11. Longo WE, Baker CC, McMillen MA, Modlin IM, Degutis LC, Zucker KA. Nonoperative management of adult blunt splenic trauma. Criteria for successful outcome. Ann Surg 1989;210:626-9. CrossRef

12. Lynch JM, Ford H, Gardner MJ, Weiner ES. Is early discharge following isolated splenic injury in the hemodynamically stable child possible? J Pediatr Surg 1993;28:1403-7. CrossRef

13. Wasvary H, Howells G, Villalba M, Madrazo B, Bendick P, DeAngelis $\mathrm{M}$, et al. Nonoperative management of adult blunt splenic trauma: a 15year experience. Am Surg 1997;63:694-9.

14. Siplovich L, Kawar B. Changes in the management of pediatric blunt splenic and hepatic injuries. J Pediatr Surg 1997;32:1464-5. CrossRef

15. Williams MD, Young DH, Schiller WR. Trend toward nonoperative management of splenic injuries. Am J Surg 1990;160:588-93. CrossRef

16. Archer LP, Rogers FB, Shackford SR. Selective nonoperative management of liver and spleen injuries in neurologically impaired adult patients. Arch Surg 1996;131:309-15. CrossRef

17. Clancy TV, Weintritt DC, Ramshaw DG, Churchill MP, Covington DL, Maxwell JG. Splenic salvage in adults at a level II community hospital trauma center. Am Surg 1996;62:1045-9.

18. Brasel KJ, Weigelt JA, Christians KK, Somberg LB. The value of process measures in evaluating an evidence-based guideline. Surgery 2003;134:605-12. CrossRef

19. Watson GA, Rosengart MR, Zenati MS, Tsung A, Forsythe RM, Peitzman AB, et al. Nonoperative management of severe blunt splenic injury: are we getting better? J Trauma 2006;61:1113-9. CrossRef

20. Cathey KL, Brady WJ Jr, Butler K, Blow O, Cephas GA, Young JS. Blunt splenic trauma: characteristics of patients requiring urgent laparotomy. Am Surg 1998;64:450-4.

21. Krause KR, Howells GA, Bair HA, Glover JL, Madrazo BL, Wasvary $\mathrm{HJ}$, et al. Nonoperative management of blunt splenic injury in adults 55 years and older: a twenty-year experience. Am Surg 2000;66:636-40.

22. Eastridge BJ, Salinas J, McManus JG, Blackburn L, Bugler EM, Cooke $\mathrm{WH}$, et al. Hypotension begins at $110 \mathrm{~mm} \mathrm{Hg:} \mathrm{redefining} \mathrm{"hypotension"}$ with data. J Trauma 2007;63:291-9. CrossRef

23. Jones D, Engelke MK, Brown ST, Swanson M. A comparison of two noninvasive methods of blood pressure measurement in the triage area. J Emerg Nurs 1996;22:111-5. CrossRef

24. Cienki JJ, DeLuca LA, Daniel N. The validity of emergency department triage blood pressure measurements. Acad Emerg Med 2004;11:237-43.

25. Skirton H, Chamberlain W, Lawson C, Ryan H, Young E. A systematic review of variability and reliability of manual and automated blood pressure readings. J Clin Nurs 2011;20:602-14. CrossRef

26. McCann UG 2nd, Schiller HJ, Carney DE, Kilpatrick J, Gatto LA, Paskanik AM, et al. Invasive arterial BP monitoring in trauma and critical care: effect of variable transducer level, catheter access, and patient position. Chest 2001;120:1322-6. CrossRef

27. Fang JF, Chen RJ, Lin BC, Hsu YB, Kao JL, Chen MF. Liver cirrhosis: an unfavorable factor for nonoperative management of blunt splenic injury. $\mathrm{J}$ Trauma 2003;54:1131-6. CrossRef

28. Levi L, Wolf A, Belzberg H. Hemodynamic parameters in patients with acute cervical cord trauma: description, intervention, and prediction of outcome. Neurosurgery 1993;33:1007-17. CrossRef

29. McVay MR, Kokoska ER, Jackson RJ, Smith SD. Throwing out the "grade" book: management of isolated spleen and liver injury based on hemodynamic status. J Pediatr Surg 2008;43:1072-6. CrossRef

30. Tataria M, Nance ML, Holmes JH 4th, Miller CC 3rd, Mattix KD, Brown RL, et al. Pediatric blunt abdominal injury: age is irrelevant and delayed operation is not detrimental. J Trauma 2007;63:608-14. CrossRef

31. Bannon MP, O’Neill CM, Martin M, Ilstrup DM, Fish NM, Barrett J. Central venous oxygen saturation, arterial base deficit, and lactate concentration in trauma patients. Am Surg 1995;61:738-45.

32. Rixen D, Raum M, Bouillon B, Lefering R, Neugebauer E; Arbeitsgemeinschaft "Polytrauma" of the Deutsche Gesellschaft fur Unfallchirurgie. Base deficit development and its prognostic significance in posttrauma critical illness: an analysis by the trauma registry of the Deutsche Gesellschaft für unfallchirurgie. Shock 2001;15:83-9. CrossRef

33. Hongcheol L, Namsoo J. Korean Trauma Assessment and Treatment course 1st ed, Koonja 2010. p. 73.

\section{ORIJINAL ÇALIŞMA - ÖZET}

\section{Travma hastalarında stabil yaşamsal bulgunun tanımındaki farklılık: Ulusal çaplı bir taramanın sonuçları}

\section{Dr. Seongpyo Mun}

Chosun Üniversitesi, Cerrahi Anabilim Dalı, Gwangju, Güney Kore

AMAÇ: Yaşamsal bulgulara (YB) dayalı hemodinamik stabilitenin (HS) künt dalak travmasının (KDT) başarılı cerrahi dışı tedavisinde (CDT) en yararlı kriter olduğu düşünülürdü. Ancak HS'nin tutarlı bir tanımı tespit edilememiştir. Ulusal çapta bir taramayla HS tanımını değerlendirmeyi ve bu farklıı̆ı yaratan faktörleri saptamayı istedik.

GEREÇ VE YÖNTEM: Ekim 2012 ile Kasım 2012 arasında birinci seviyede bir travma merkezinin travma ve acil cerrahi bölümüne HS tanımını içeren bir anket gönderildi. Variyans analizi, t-testi, $\chi^{2}$ testi ve lojistik regresyon analiziyle veriler karşılaştıııldı.

BULGULAR: 563 doktorun 507'si (\%90) yanıt vermişti. Kırk sekizinin yanıtları eksikti ve 459 (\%8I.5) yanıt incelendi. Kan basıncı (KB), hipotansiyonun kestirim değeri, KB'yi ölçüm tekniği, hipotansiyonun süresi, HS'nin belirleyicisi olarak kalp hızının (KH) kullanılıp kullanılmadığı, hastada komorbidite varlığına veya çocuk hasta olduğuna göre HS tanımlarında anlamlı farklılık mevcuttu. Doktorların \%9I.5'i HS'yi tanımlamada kafalarının karışık olduğu ve daha somut belirleyicilere gerek duydukları yanıtını verdi. Her halde yanıt verenlerin \%90'ı HS'yi tanımlamak için laboratuvar testlerinden yararlanmamaktaydı.

TARTIŞMA: Birçok travmatoloji uzmanı HS’yi tanımlamak için yalnızca YB'yi kullanmaktadır. İşte bu nedenle hangi hastanın hemodinamik açıdan stabil olduğunu tanımlamada karmaşa yaşanmaktadır. Baz eksikliği veya laktat tayini gibi daha somut belirleyiciler daha yararlı ek bilgiler sağlayabilir. Anahtar sözcükler: Farklılı; hemodinamik instabilite; künt dalak travması; tanım; tarama.

Ulus Travma Acil Cerrahi Derg 2015;21(6):432-439 doi: 10.5505/tjtes.2015.83093 